\title{
Pengukuran tingkat kesuksesan penerapan website Penerimaan Mahasiswa Baru (PMB) online di perguruan tinggi swasta dengan pendekatan Human Organization Technology (HOT) Fit model
}

\author{
Ahmad Heru Mujianto a, Bambang Soedijono ${ }^{b}$, Henderi ${ }^{c}$ \\ a,b,c Magister Teknik Informatika, Universitas Amikom, Yogyakarta, Indonesia \\ email:aahmadheru13@gmail.com, chenderi@mail.ugm.ac.id
}

\begin{tabular}{l} 
I N F O A R T I K E L \\
\hline Sejarah artikel: \\
Menerima 9 Februari 2017 \\
Revisi 29 Maret 2017 \\
Diterima 29 Maret 2017 \\
Online 18 Desember 2017 \\
\hline Kata kunci: \\
HOT Fit \\
Human Organization \\
Technology \\
Penerimaan Mahasiswa \\
Baru \\
PMB \\
PTS
\end{tabular}

Keywords:

Admission of new students HOT Fit

Human Organization

Technology

Private Higher Education

PHE

\section{Style APA dalam mensitasi} artikel ini:

Mujianto, A. H., Soedijono, B., \& Henderi, H. (2017). Pengukuran tingkat kesuksesan penerapan website Penerimaan Mahasiswa Baru (PMB) online di perguruan tinggi swasta dengan pendekatan Human Organization Technology (HOT) Fit model. Register: Jurnal Ilmiah Teknologi Sistem Informasi, 3(1), 24-33.

\begin{abstract}
A B S T R A K
Beberapa Perguruan Tinggi Swasta (PTS) di Jombang menerapkan proses seleksi Penerimaan Mahasiswa Baru (PMB) online, sehingga pendaftar cukup mendaftar melalui website PMB online milik masing-masing PTS, tanpa perlu ke Perguruan Tinggi (PT) tersebut. Namun dalam pelaksanaanya masih terdapat calon mahasiswa yang mendaftar secara langsung ke kantor PMB PTS, hal tersebut menjadikan perlunya pengukuran tingkat kesuksesan penerapan website PMB online di PTS. Selain itu, selama ini website PMB online PTS di Jombang belum pernah dilakukan evaluasi untuk mengetahui tingkat keberhasilannya. HOT (Human Organization Technology) Fit model merupakan model kesuksesan yang dapat dijadikan model dalam mengevaluasi sistem informasi. Terdapat 7 variabel yang digunakan HOT Fit, yaitu kualitas sistem (system quality), kualitas informasi (information quality), kualitas layanan (service quality), pengguna sistem (system use), kepuasan pengguna (user satisfaction), manfaat (net beneFits), struktur organisasi (organization structure). Hasil penelitian menunjukkan terdapat 3 indikator penilaian dengan nilai kepuasan di bawah $85 \%$, yaitu kecepatan waktu respon $76,1 \%$; adanya fasilitas bantuan $71,6 \%$; dan kepuasan tampilan $64,2 \%$. Sehingga 3 indikator tersebut perlu ditingkat lagi untuk mendapatkan hasil yang lebih baik dan dapat mengoptimalkan penerapan website PMB online PTS di Jombang.
\end{abstract}

\section{ABSTRACT}

Private Higher Education (PHE) in Jombang apply online admission of new students selection process, so applicants simply register through admission of new students online website owned by their respective private universities, without needing to the university. But in the implementation there are still prospective students who apply directly to the office of admission of new students PHE, it makes the need to measure the success rate of admission of new students website online application in PHE. Also, so far admission of new students online website PHE in Jombang has never been evaluated to determine the success rate. HOT (Human Organization Technology) Fit model is a model of success that can be used as a model for evaluating information systems. There are seven variables used by HOT Fit, i.e., system quality, information quality, service quality, system use, user satisfaction, net beneFits, organizational structure (organization structure). The result of the research shows that there are three assessment indicators with satisfaction value below $85 \%$, the response time is $76,1 \%$; the availability of $71.6 \%$ of aid facilities; and $64.2 \%$ display satisfaction. So that three indicators need to be increased again to get better results and can optimize the implementation of admission of new students website online PHE in Jombang.

(c) 2017 Register: Jurnal Ilmiah Teknologi Sistem Informasi. Semua hak cipta dilindungi undang-undang. 


\section{Pendahuluan}

Penerimaan Mahasiswa Baru (PMB) atau Admission of New Students adalah semua kegiatan yang dimulai dari proses penerimaan mahasiswa baru, dilanjutkan dengan seleksi administrasi mahasiswa baru, sampai akhirnya pengumuman kelulusan mahasiswa baru. Proses penerimaan mahasiswa baru merupakan kegiatan rutin setiap tahunnya, kegiatan ini dapat dikatakan sebagai titik awal proses pencarian calon mahasiswa baru yang berkualitas (Utomo, 2014). Di mana calon mahasiswa akan mencari segala informasi yang berkaitan dengan universitas yang akan dipilihnya, baik dengan datang langsung ke perguruan tinggi atau dengan mengakses website PMB, yang selanjutnya calon mahasiswa akan melakukan pendaftaran secara online melalui website PMB. Sehingga dibutuhkan website PMB online yang mampu memberikan manfaat bagi para penggunanya dan tidak membingungkan.

Perguruan Tinggi Swasta (PTS) di Jombang telah menerapkan proses PMB online. Berdasarkan hasil wawancara dengan pengelola PMB, penerapan PMB online dilatarbelakangi karena adanya tuntutan kebutuhan dalam kemajuan teknologi, sehingga tetap bisa bersaing dengan pesaingnya. Selain itu, berdasarkan data mahasiswa dari tahun ke tahun, diketahui bahwa asal mahasiswa tidak hanya dari dalam kota, akan tetapi banyak juga yang berasal dari luar kota, bahkan luar provinsi Jawa Timur, sehingga dengan proses pendaftar online akan sangat membantu para pendaftar yang berasal dari luar kota maupun luar provinsi. Selanjutnya dalam hal perancangan website PMB, PTS hanya berdasarkan asumsi perancangnya, dan sejauh ini belum dilakukan evaluasi terkait kesuksesan penerapan website PMB online. Oleh karena itu, perlu adanya pengukuran tingkat kesuksesan penerapan website PMB online dari sisi pengguna untuk mengetahui sejauh mana tingkat keberhasilan website PMB online berdasarkan hasil penilaian yang dilakukan oleh pengguna. Sehingga website PMB online mampu membantu calon mahasiswa dalam proses pendaftaran.

Penelitian sebelumnya yang dilakukan oleh Nugroho, Utami, dan Taufiq (2013), yang juga melakukan analisis perbandingan kualitas pelayanan PMB online dengan menggunakan Model Kesuksesan DeLone dan McLean (D\&M). Penelitian lain dilakukan Krisbiantoro, Suyanto, dan Luthfi (2015), melakukan evaluasi terhadap keberhasilan implementasi sistem informasi perpustakaan SliMS (Senayan Libary Management System) di STMIK AMIKOM Purwokerto, dengan mengacu pada model evaluasi HOT-FIT. Penelitian serupa juga dilakukan oleh Pant (2015) yang melakukan evaluasi terhadap website perpustakaan Universitas Delhi, tetapi dalam penelitiannya menggunakan model evaluasi usability. Evaluasi usability juga diterapkan dalam penelitian Wei, Chang, dan Cheng (2015) yang melakukan pengukuran tingkat kegunaan dari aplikasi perpustakaan mobile Universitas Chongqing dengan variabel yang menjadi pengukuran adalah efektivitas dan efisiensi dari aplikasi, serta kepuasan pengguna. Sedangkan peneliti melakukan pengukuran kesuksesan penerapan website PMB online PTS di Jombang menggunakan HOT (Human, Organization, Technology) Fit model dengan tujuh variabel yaitu System Quality, Information Quality, Service Quality, System Use, User Satisfaction, Net BeneFits dan Structure Organization.

Berdasarkan perumusan masalah di atas, dalam penelitian ini akan dilakukan pengukuran tingkat kesuksesan penerapan website PMB online dengan pendekatan HOT Fit model yang mengambil studi kasus pada PMB di PTS Jombang. Diharapkan dengan adanya penelitian ini mampu mengetahui aspek-aspek mana saja yang masih lemah sehingga mampu ditingkatkan untuk mengoptimalkan penerapan website PMB online di PTS Jombang.

\section{Metode Penelitian}

Penelitian ini jika dilihat dari tujuannya termasuk dalam kategori evaluasi riset, di mana dalam penelitian ini dilakukan sebuah evaluasi terhadap penerapan website PMB online untuk mengukur sejauh mana tingkat kesuksesan penerapan website PMB online. Berikut ini alur penelitian yang ditunjukkan pada Gambar 1.

Penelitian yang dilakukan peneliti terbagi atas tiga tahapan, yaitu tahap awal, tahap pengolahan data, dan tahap perumusan hasil.

a. Tahap awal

Pada tahap awal, peneliti melakukan studi literature dengan membaca dan mempelajari berbagai referensi yang relevan. Selain itu peneliti juga mengumpulkan data-data yang relevan 
meliputi observasi website PMB online PTS di Jombang, serta melakukan wawancara kepada pengelola PMB.

b. Tahap pengolahan data

Tahap ini dimulai dengan pembuatan instrumen kuesioner dengan jenis kuesioner tertutup. Selanjutnya kuesioner akan dilakukan uji validitas dan reliabilitas. Berdasarkan hasil kuesioner yang telah diisi oleh para responden selanjutnya akan dilakukan analisis dan pengolahan data hasil kuesioner, yang kemudian akan menjadi dasar dalam perumusan hasil penelitian.

c. Tahap perumusan hasil

Tahap terakhir adalah mengambil kesimpulan dan dari hasil penelitian dan memberikan saransaran terkait pengukuran penerapan website PMB kepada pengelola website PMB PTS di Jombang.

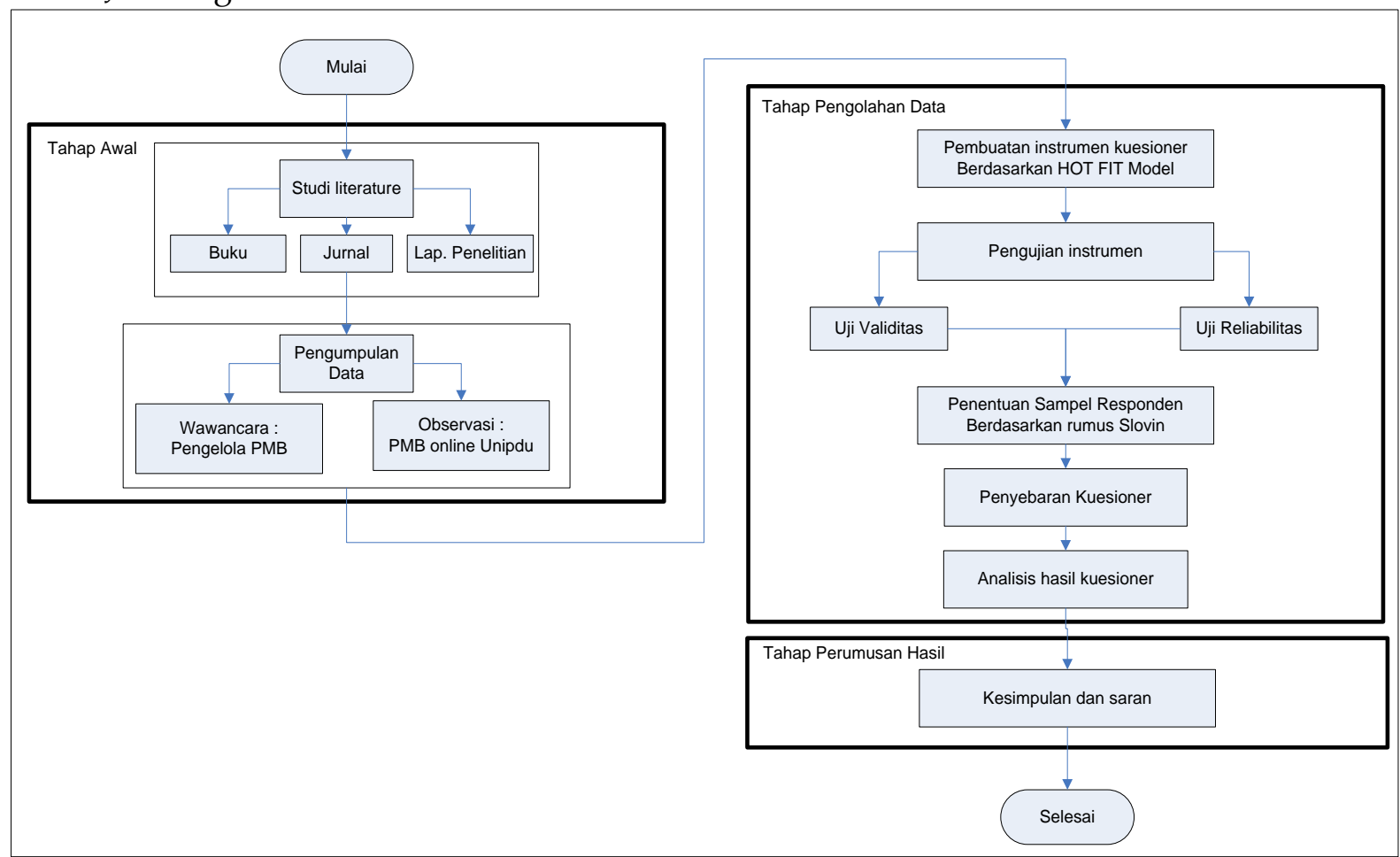

Gambar 1. Alur Penelitian

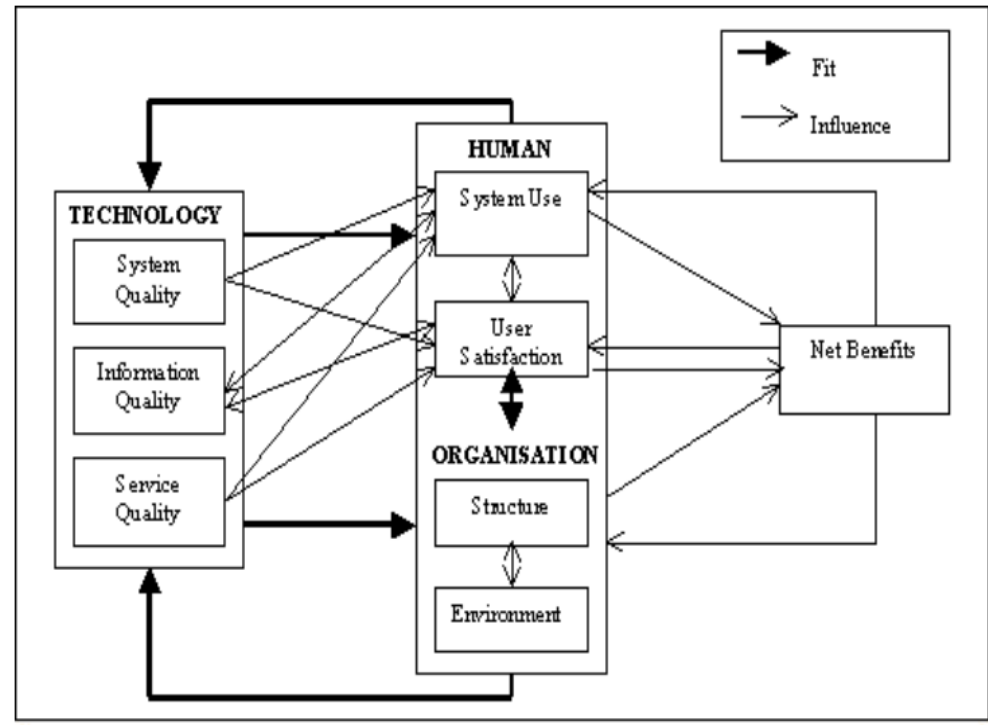

Gambar 2. Kerangka HOT Fit (Yusof, Paul, \& Stergioulas, 2006)

Metode penilaian yang digunakan untuk mengukur website PMB adalah dengan pendekatan HOT Fit model, di mana website adalah suatu halaman di internet yang terdiri dari teks, gambar, suara, 

Sedangkan HOT Fit model merupakan model kesuksesan yang dapat dipergunakan dalam melakukan penilaian sistem informasi yang dikemukakan oleh (Yusof, Paul, \& Stergioulas, 2006). Model ini dipilih karena model ini lengkap dalam aspek penilaian yang dilakukan dan paling sesuai dengan permasalahan yang ada dibandingkan dengan model lain, di mana model ini menempatkan tiga bagian penting yaitu Manusia (Human) Organisasi (Organization) dan Teknologi (Technology) (Krisbiantoro, Suyanto, \& Luthfi, 2015). Berikut kerangka HOT Fit yang ditunjukkan Gambar 2.

Model HOT Fit terdiri 3 komponen utama yaitu manusia (human) dengan indikator penilaian dari sisi penggunaan sistem (system use) dan kepuasan pengguna (user satisfaction), organisasi (organization) dengan indikator penilaian meliputi struktur organisasi (structure) dan lingkungan organisasi (Environment), dan terakhir teknologi (Technology) dengan indikator penilaian kualitas sistem (system quality), kualitas informasi (information quality) dan kualitas layanan (services quality). Ketiga komponen tersebut akan saling berkaitan dengan manfaat yang diberikan (net benefits) (Krisbiantoro, Suyanto, \& Luthfi, 2015).

Setelah mempelajari komponen yang terdapat dalam model HOT Fit, selanjutnya peneliti mengindentifikasikan variabel dan indikator variabel yang digunakan dalam pembuatan instrumen kuesioner untuk melakukan penilaian website PMB online PTS di Jombang. Berikut data instrumen kuesioner yang dapat dilihat pada Tabel 1.

Tabel 1. Instrumen Kuesioner Website PMB Online PTS di Jombang

(diadaptasi dari Nugroho, Utami, dan Taufiq (2013) dan Krisbiantoro, Suyanto, dan Luthfi (2015))

\begin{tabular}{|c|c|c|c|}
\hline No & Variabel & Indikator & $\begin{array}{c}\text { Jumlah } \\
\text { Pertanyaan }\end{array}$ \\
\hline \multirow[t]{6}{*}{1} & Kualitas sistem (Ks) & Ks1 = Kemudahan untuk digunakan & 1 \\
\hline & (System quality) & Ks2 = Kemudahan untuk dipelajari & 1 \\
\hline & & Ks3 = Kecepatan waktu respon & 1 \\
\hline & & Ks4 = Jarang mengalami error & 1 \\
\hline & & Ks5 = Adanya fasilitas petunjuk penggunaan (bantuan) & 1 \\
\hline & & Ks6 = Keamanan system & 1 \\
\hline \multirow[t]{6}{*}{2} & Kualitas informasi (Ki) & Ki1 = Kelengkapan isi & 1 \\
\hline & (Information quality) & Ki2 = Penyajian informasi & 1 \\
\hline & & Ki3 = Relevan & 1 \\
\hline & & Ki4 = Mudah dibaca & 1 \\
\hline & & Ki5 = Informasi dapat dipertanggungjawabkan & 1 \\
\hline & & Ki6 = Ketepatan waktu & 1 \\
\hline \multirow[t]{2}{*}{3} & Kualitas layanan (K1) & $\mathrm{K} 11=$ Jaminan & 1 \\
\hline & (Service quality) & $\mathrm{K} 12$ = Empati & 1 \\
\hline 4 & $\begin{array}{l}\text { Pengguna sistem (Ps) } \\
\text { (System use) }\end{array}$ & Ps $=$ Pengetahuan pengguna & 1 \\
\hline \multirow[t]{3}{*}{5} & Kepuasan pengguna & Kp1 = Kepuasan terhadap informasi & 1 \\
\hline & $(\mathrm{Kp})$ & Kp2 = Kepuasan terhadap fitur & 1 \\
\hline & (User satisfaction) & Kp3 = Kepuasan tampilan & 1 \\
\hline \multirow[t]{2}{*}{6} & Manfaat (Mn) & Mn1 = Efektivitas dan efesiensi & 1 \\
\hline & (Net benefits) & Mn2 = Menambah pengetahuan & 1 \\
\hline \multirow[t]{4}{*}{7} & Struktur organisasi & So1 = Peningkatan kinerja & 1 \\
\hline & (So) & So2 $=$ Pembaharuan perangkat & 1 \\
\hline & (Organization structure) & So3 = Dukungan & 1 \\
\hline & & So $4=$ Fasilitas & 1 \\
\hline \multicolumn{2}{|c|}{ Total Pertanyaan } & & 24 \\
\hline
\end{tabular}

\section{Hasil Penelitian dan Pembahasan}

Instrumen kuesioner yang telah terindentifikasi, selanjutnya dibuat butir-butir pertanyaan dalam melakukan penilaian website PMB online PTS di Jombang. Tersusun 24 butir pertanyaan yang selanjutnya dilakukan uji validitas dan reliabilitas.

Berdasarkan hasil uji validitas dari 24 butir pertanyaan yang diujikan, terdapat 3 butir pertanyaan yang memiliki nilai signifikansi $>0,05$ yaitu, pada butir pertanyaan nomor 2 yang 

merupakan indikator Kualitas sistem 2 (Ks2), butir pertanyaan nomor 4 yang merupakan indikator
Kualitas sistem 4 (Ks4), dan butir pertanyaan nomor 19 yang merupakan indikator Manfaat 1 (Mf1). Sehingga dari 3 butir pertanyaan tersebut dinyatakan tidak valid dan harus dihilangkan untuk selanjutnya dilakukan uji reliabilitas. Sedangkan dari hasil uji reliabilitas dapat diketahui bahwa seluruh butir pertanyaan memiliki reliabilitas yang baik, sehingga tersusun 20 butir pertanyaan kuesioner yang siap digunakan dan disebarkan kepada responden.

\subsection{Penyebaran kuesioner}

Metode pengambil sampel pada penelitian ini menggunakan teknik Simple Random Sampling, yang artinya pengambilan sampel dari total populasi dilakukan secara acak tanpa memperhatikan tingkatan dalam populasi (Gunawan, 2015). Kuesioner disebarkan kepada 63 responden calon mahasiswa baru yang diwakili oleh siswa sekolah lanjutan tingkat atas (SLTA) kelas XII dan 4 pegawai PMB di salah satu PTS Jombang. Tabel 2 adalah karakteristik responden pada kuesioner penilaian PMB online PTS di Jombang.

Tabel 2. Karakteristik Responden

\begin{tabular}{llcc}
\hline & Kriteria & Jumlah & Persentase \\
\hline Jenis Kelamin & Laki-laki & 25 & $37 \%$ \\
& Perempuan & 42 & $63 \%$ \\
\multirow{3}{*}{ Pendidikan } & Jumlah & 67 & $100 \%$ \\
& SLTA & 63 & $94 \%$ \\
& S1 & 3 & $5 \%$ \\
\multirow{3}{*}{ Usia } & S2 & 1 & $1 \%$ \\
& Jumlah & 67 & $100 \%$ \\
& $16-20$ & 63 & $94 \%$ \\
& $21-30$ & 3 & $5 \%$ \\
& $31-40$ & 1 & $1 \%$ \\
& Jumlah & 67 & $100 \%$ \\
\hline
\end{tabular}

\subsection{Pengolahan data}

Hasil pengisian kuesioner oleh responden selanjutnya diolah dengan bantuan aplikasi SPSS dengan teknik pengolahan menggunakan analisis statistik deskriptif. Analisis statistik deskriptif adalah statistik yang berfungsi untuk memberikan gambaran secara umum terhadap obyek yang diteliti berdasarkan data-data yang telah dikumpulkan dengan model penyajian data seperti analisis frekuensi (Sugiyono, 2010). Analisis frekuensi akan menampilkan data-data berdasarkan frekuensi pengisian kuesioner oleh responden. Gambar 3 adalah hasil analisis frekuensi untuk setiap butir pertanyaan.

\begin{tabular}{|c|c|c|c|c|c|c|c|c|c|c|c|}
\hline \multicolumn{6}{|c|}{ KS1 } & \multicolumn{6}{|c|}{ KS2 } \\
\hline & & Frequency & Percent & Valid Percent & $\begin{array}{c}\text { Cumulative } \\
\text { Percent }\end{array}$ & & & Frequency & Percent & Valid Percent & $\begin{array}{l}\text { Cumulative } \\
\text { Percent }\end{array}$ \\
\hline \multirow[t]{4}{*}{ Valid } & 1 & 1 & 1,5 & 1,5 & 1,5 & \multirow[t]{4}{*}{ Valid } & 1 & 16 & 23,9 & 23,9 & 23,9 \\
\hline & 2 & 42 & 62,7 & 62,7 & 64,2 & & 2 & 39 & 58,2 & 58,2 & 82,1 \\
\hline & 3 & 24 & 35,8 & 35,8 & 100,0 & & 3 & 12 & 17,9 & 17,9 & 100,0 \\
\hline & Total & 67 & 100,0 & 100,0 & & & Total & 67 & 100,0 & 100,0 & \\
\hline \multicolumn{6}{|c|}{ KS3 } & \multicolumn{6}{|c|}{ KS4 } \\
\hline & & Frequency & Percent & Valid Percent & $\begin{array}{c}\text { Cumulative } \\
\text { Percent }\end{array}$ & & & Frequency & Percent & Valid Percent & $\begin{array}{l}\text { Cumulative } \\
\text { Percent }\end{array}$ \\
\hline \multirow[t]{5}{*}{ Valid } & 0 & 1 & 1,5 & 1,5 & 1,5 & \multirow[t]{4}{*}{ Valid } & $\overline{1}$ & 5 & 7.5 & 7,5 & $\overline{7.5}$ \\
\hline & 1 & 18 & 26,9 & 26,9 & 28,4 & & 2 & 30 & 44,8 & 44,8 & 52,2 \\
\hline & 2 & 34 & 50,7 & 50,7 & 79,1 & & 3 & 32 & 47,8 & 47,8 & \multirow{2}{*}{100,0} \\
\hline & 3 & 14 & 20,9 & 20,9 & 100,0 & & Total & 67 & 100,0 & 100,0 & \\
\hline & Total & 67 & 100,0 & 100,0 & & & & & & & \\
\hline
\end{tabular}

Gambar 3. Analisis frekuensi kualitas sistem di PTS Jombang

1) Kualitas Sistem

Gambar 3 adalah hasil analisis frekuensi untuk butir pertanyaan nomor 1 sampai nomor 4, yang terkait dengan variabel kualitas sistem. Hasil analisis frekuensi yang ditunjukkan pada Gambar 3 diketahui bahwa:

a. Indikator kemudahan untuk digunakan (Ks1), sebanyak 1 responden menjawab Tidak Setuju (TS) dengan persentase 1,5\%, selanjutnya 42 responden menjawab Setuju (S) dengan persentase 
$62,7 \%$, dan 24 responden menjawab Sangat Setuju (SS) dengan persentase 35,8\%. Sehingga indikator kemudahan untuk digunakan memiliki tingkat kesuksesan sangat baik.

b. Indikator kecepatan waktu respon (Ks2), sebanyak 16 responden menjawab Tidak Setuju (TS) dengan persentase $23,9 \%$, selanjutnya 39 responden menjawab Setuju (S) dengan persentase $58,2 \%$, dan 12 responden menjawab Sangat Setuju (SS) dengan persentase 17,9\%. Sehingga indikator kecepatan waktu respon memiliki tingkat kesuksesan baik, namun karena nilai TS yang cukup tinggi, maka indikator kecepatan waktu respon perlu ditingkatkan.

c. Indikator fasilitas petunjuk penggunaan (Ks3), sebanyak 1 responden menjawab Sangat Tidak Setuju (STS) dengan persentase 1,5\%, selanjutnya 18 responden menjawab Tidak Setuju (TS) dengan persentase $26,9 \%$, Sebanyak 34 responden menjawab Setuju (S) dengan persentase 50,7\%, dan 14 responden menjawab Sangat Setuju (SS) dengan persentase 20,9\%. Sehingga indikator fasilitas petunjuk penggunaan memiliki tingkat kesuksesan baik, tetapi dengan nilai STS dan TS yang tinggi, maka indikator fasilitas petunjuk penggunaan perlu ditingkatkan.

d. Indikator keamanan sistem (Ks4), sebanyak 5 responden menjawab Tidak Setuju (TS) dengan persentase $7,5 \%$, selanjutnya 30 responden menjawab Setuju (S) dengan persentase $44,8 \%$, dan 32 responden menjawab Sangat Setuju (SS) dengan persentase 47,8\%. Sehingga indikator keamanan sistem memiliki tingkat kesuksesan sangat baik.

2) Kualitas Informasi

Gambar 4 adalah hasil analisis frekuensi untuk butir pertanyaan nomor 5 sampai 10 yang terkait dengan variabel kualitas informasi.

\begin{tabular}{|c|c|c|c|c|c|c|c|c|c|c|c|}
\hline \multicolumn{6}{|c|}{ KI1 } & \multicolumn{6}{|c|}{ K14 } \\
\hline & & Frequency & Percent & Valid Percent & $\begin{array}{c}\text { Cumulative } \\
\text { Percent }\end{array}$ & & & Frequency & Percent & Valid Percent & $\begin{array}{l}\text { Cumulative } \\
\text { Percent }\end{array}$ \\
\hline \multirow[t]{4}{*}{ Valid } & 1 & 7 & 10,4 & 10,4 & 10,4 & \multirow[t]{4}{*}{ Valid } & 1 & 4 & 6,0 & 6,0 & 6,0 \\
\hline & 2 & 42 & 62,7 & 62,7 & 73,1 & & 2 & 42 & 62,7 & 62,7 & 68,7 \\
\hline & 3 & 18 & 26,9 & 26,9 & 100,0 & & 3 & 21 & 31,3 & 31,3 & 100,0 \\
\hline & Total & 67 & 100,0 & 100,0 & & & Total & 67 & 100,0 & 100,0 & \\
\hline \multicolumn{6}{|c|}{ KI2 } & \multicolumn{6}{|c|}{ K15 } \\
\hline & & Frequency & Percent & Valid Percent & $\begin{array}{c}\text { Cumulative } \\
\text { Percent }\end{array}$ & & & Frequency & Percent & Valid Percent & $\begin{array}{c}\text { Cumulative } \\
\text { Percent }\end{array}$ \\
\hline \multirow[t]{4}{*}{ Valid } & 1 & 1 & 1,5 & 1,5 & 1,5 & \multirow[t]{4}{*}{ Valid } & 1 & 2 & 3,0 & 3,0 & 3,0 \\
\hline & 2 & 45 & 67,2 & 67,2 & 68,7 & & 2 & 40 & 59,7 & 59,7 & 62,7 \\
\hline & 3 & 21 & 31,3 & 31,3 & 100,0 & & 3 & 25 & 37,3 & 37,3 & 100,0 \\
\hline & Total & 67 & 100,0 & 100,0 & & & Total & 67 & 100,0 & 100,0 & \\
\hline \multicolumn{6}{|c|}{ K13 } & \multicolumn{6}{|c|}{ K16 } \\
\hline & & Frequency & Percent & Valid Percent & $\begin{array}{c}\text { Cumulative } \\
\text { Percent }\end{array}$ & & & Frequency & Percent & Valid Percent & $\begin{array}{c}\text { Cumulative } \\
\text { Percent }\end{array}$ \\
\hline \multirow[t]{4}{*}{ Valid } & 1 & 1 & 1,5 & 1,5 & 1,5 & \multirow[t]{4}{*}{ Valid } & 1 & 6 & 9,0 & 9,0 & 9,0 \\
\hline & 2 & 39 & 58,2 & 58,2 & 59,7 & & 2 & 40 & 59,7 & 59,7 & 68,7 \\
\hline & 3 & 27 & 40,3 & 40,3 & 100,0 & & 3 & 21 & 31,3 & 31,3 & 100,0 \\
\hline & Total & 67 & 100,0 & 100,0 & & & Total & 67 & 100,0 & 100,0 & \\
\hline
\end{tabular}

Gambar 4. Analisis frekuensi kualitas sistem di PTS Jombang

a. Indikator kelengkapan isi (Ki1), sebanyak 7 responden menjawab Tidak Setuju (TS) dengan persentase 10,4\%, selanjutnya 42 responden menjawab Setuju (S) dengan persentase $62,7 \%$, dan 18 responden menjawab Sangat Setuju (SS) dengan persentase 26,9\%. Sehingga indikator kelengkapan isi memiliki tingkat kesuksesan sangat baik.

b. Indikator penyajian informasi (Ki2), sebanyak 1 responden menjawab Tidak Setuju (TS) dengan persentase 1,5\%, selanjutnya 45 responden menjawab Setuju (S) dengan persentase $67,2 \%$, dan 21 responden menjawab Sangat Setuju (SS) dengan persentase 31,3\%. Sehingga indikator penyajian informasi memiliki tingkat kesuksesan sangat baik.

c. Indikator relevan (Ki3), sebanyak 1 responden menjawab Tidak Setuju (TS) dengan persentase 1,5\%, selanjutnya 39 responden menjawab Setuju (S) dengan persentase 58,2\%, dan 27 responden menjawab Sangat Setuju (SS) dengan persentase 40,3\%. Sehingga indikator relevan memiliki tingkat kesuksesan sangat baik. 
d. Indikator mudah dibaca (Ki4), sebanyak 4 responden menjawab Tidak Setuju (TS) dengan persentase $6,0 \%$, selanjutnya 42 responden menjawab Setuju (S) dengan persentase $62,7 \%$, dan 21 responden menjawab Sangat Setuju (SS) dengan persentase 31,3\%. Sehingga indikator mudah dibaca memiliki tingkat kesuksesan sangat baik.

e. Indikator informasi dapat dipertanggungjawabkan (Ki5), sebanyak 2 responden menjawab Tidak Setuju (TS) dengan persentase 3,0\%, selanjutnya 40 responden menjawab Setuju (S) dengan persentase 59,7\%, dan 25 responden menjawab Sangat Setuju (SS) dengan persentase $37,3 \%$. Sehingga indikator informasi memiliki tingkat kesuksesan sangat baik.

f. Indikator ketepatan waktu (Ki6), sebanyak 6 responden menjawab Tidak Setuju (TS) dengan persentase 9\%, selanjutnya 40 responden menjawab Setuju (S) dengan persentase 59,7\%, dan 21 responden menjawab Sangat Setuju (SS) dengan persentase 31,3\%. Sehingga indikator ketepatan waktu memiliki tingkat kesuksesan sangat baik.

3) Kualitas Layanan

Gambar 5 adalah hasil analisis frekuensi untuk butir pertanyaan nomor 11 dan 12 yang terkait dengan variabel kualitas layanan.

\begin{tabular}{|c|c|c|c|c|c|c|c|c|c|c|c|}
\hline \multicolumn{6}{|c|}{ KL1 } & \multicolumn{6}{|c|}{ KL2 } \\
\hline & & Frequency & Percent & Valid Percent & $\begin{array}{c}\text { Cumulative } \\
\text { Percent }\end{array}$ & & & Frequency & Percent & Valid Percent & $\begin{array}{c}\text { Cumulative } \\
\text { Percent }\end{array}$ \\
\hline \multirow[t]{4}{*}{ Valid } & 1 & 3 & 4,5 & 4,5 & 4,5 & Valid & 1 & 5 & 7,5 & 7,5 & 7,5 \\
\hline & 2 & 45 & 67,2 & 67,2 & 71,6 & & 2 & 35 & 52,2 & 52,2 & 59,7 \\
\hline & 3 & 19 & 28,4 & 28,4 & 100,0 & & 3 & 27 & 40,3 & 40,3 & 100,0 \\
\hline & Total & 67 & 100,0 & 100,0 & & & Total & 67 & 100,0 & 100,0 & \\
\hline
\end{tabular}

Gambar 5. Analisis frekuensi kualitas layanan di PTS Jombang

Hasil analisis frekuensi yang ditunjukkan pada Gambar 5 diketahui bahwa :

a. Indikator jaminan (K11), sebanyak 3 responden menjawab Tidak Setuju (TS) dengan persentase $4,5 \%$, selanjutnya 45 responden menjawab Setuju (S) dengan persentase 67,2\%, dan 19 responden menjawab Sangat Setuju (SS) dengan persentase 28,4\%. Sehingga indikator jaminan memiliki tingkat kesuksesan sangat baik.

b. Indikator empati (K12), sebanyak 5 responden menjawab Tidak Setuju (TS) dengan persentase $7,5 \%$, selanjutnya 35 responden menjawab Setuju (S) dengan persentase $52,2 \%$, dan 27 responden menjawab Sangat Setuju (SS) dengan persentase 40,3\%. Sehingga indikator empati memiliki tingkat kesuksesan sangat baik.

\begin{tabular}{|c|c|c|c|c|c|}
\hline \multicolumn{6}{|c|}{ PS } \\
\hline & & Frequency & Percent & Valid Percent & $\begin{array}{c}\text { Cumulative } \\
\text { Percent }\end{array}$ \\
\hline Valid & 0 & 1 & 1,5 & 1,5 & 1,5 \\
\hline & 1 & 8 & 11,9 & 11,9 & 13,4 \\
\hline & 2 & 36 & 53,7 & 53,7 & 67,2 \\
\hline & 3 & 22 & 32,8 & 32,8 & 100,0 \\
\hline & Total & 67 & 100,0 & 100,0 & \\
\hline
\end{tabular}

Gambar 6. Analisis frekuensi pengguna sistem di PTS Jombang

4) Pengguna Sistem

Gambar 6 adalah hasil analisis frekuensi untuk butir pertanyaan nomor 13, yang terkait dengan pengguna sistem. Hasil analisis frekuensi yang ditunjukkan pada Gambar 6, diketahui bahwa indikator pengetahuan pengguna (Ps) sebanyak 1 responden menjawab Sangat Tidak Setuju (STS) dengan persentase 1,5\%, Sebanyak 8 responden menjawab Tidak Setuju (TS) dengan persentase $11,9 \%$, selanjutnya 36 responden menjawab Setuju (S) dengan persentase $53,7 \%$, dan 22 responden menjawab Sangat Setuju (SS) dengan persentase 32,8\%. Sehingga indikator pengetahuan pengguna memiliki tingkat kesuksesan sangat baik.

5) Kepuasan Pengguna

Gambar 7 adalah hasil analisis frekuensi untuk butir pertanyaan nomor 14 sampai 16 yang terkait dengan indikator kepuasan pengguna. 


\begin{tabular}{|c|c|c|c|c|c|c|c|c|c|c|c|}
\hline \multicolumn{6}{|c|}{ KP1 } & \multicolumn{6}{|c|}{$\overline{\mathrm{KP} 2}$} \\
\hline & & Frequency & Percent & Valid Percent & $\begin{array}{c}\text { Cumulative } \\
\text { Percent }\end{array}$ & & & Frequency & Percent & Valid Percent & $\begin{array}{c}\text { Cumulative } \\
\text { Percent }\end{array}$ \\
\hline \multirow[t]{6}{*}{ Valid } & 1 & 2 & 3,0 & 3,0 & 3,0 & Valid & 1 & 3 & 4,5 & 4,5 & $\overline{4,5}$ \\
\hline & 2 & 49 & 73,1 & 73,1 & 76,1 & & 2 & 49 & 73,1 & 73,1 & 77,6 \\
\hline & 3 & 16 & 23,9 & 23,9 & 100,0 & & 3 & 15 & 22,4 & 22,4 & 100,0 \\
\hline & Total & 67 & 100,0 & 100,0 & & & Total & 67 & 100,0 & 100,0 & \\
\hline & \multicolumn{5}{|c|}{ KP3 } & & & & & & \\
\hline & & Frequency & Percent & Valid Percent & $\begin{array}{c}\text { Cumulative } \\
\text { Percent }\end{array}$ & & & & & & \\
\hline \multirow[t]{4}{*}{ Valid } & 1 & 24 & 35,8 & 35,8 & 35,8 & & & & & & \\
\hline & 2 & 31 & 46.3 & 46.3 & 82.1 & & & & & & \\
\hline & 3 & 12 & 17,9 & 17,9 & 100,0 & & & & & & \\
\hline & Total & 67 & 100,0 & 100,0 & & & & & & & \\
\hline
\end{tabular}

Gambar 7. Analisis frekuensi kepuasan pengguna pengguna di PTS Jombang

Hasil analisis frekuensi yang ditunjukkan pada Gambar 7 diketahui bahwa :

a. Indikator kepuasan terhadap informasi (Kp1), sebanyak 2 responden menjawab Tidak Setuju (TS) dengan persentase 3,0\%, selanjutnya 49 responden menjawab Setuju (S) dengan persentase $73,1 \%$, dan 16 responden menjawab Sangat Setuju (SS) dengan persentase 23,9\%. Sehingga indikator kepuasan informasi memiliki tingkat kesuksesan sangat baik.

b. Indikator kepuasan terhadap fitur (Kp2), sebanyak 3 responden menjawab Tidak Setuju (TS) dengan persentase $4,5 \%$, selanjutnya 49 responden menjawab Setuju (S) dengan persentase $73,1 \%$, dan 15 responden menjawab Sangat Setuju (SS) dengan persentase 22,4\%. Sehingga indikator kepuasan fitur memiliki tingkat kesuksesan sangat baik.

c. Indikator kepuasan tampilan (Kp3), sebanyak 24 responden menjawab Tidak Setuju (TS) dengan persentase 35,8\%, selanjutnya 31 responden menjawab Setuju (S) dengan persentase 46,3\%, dan 12 responden menjawab Sangat Setuju (SS) dengan persentase 17,9\%. Sehingga indikator kepuasan tampilan memiliki tingkat kesuksesan baik, tetapi dengan nilai TS yang tinggi, maka indikator kepuasan tampilan perlu ditingkatkan.

6) Manfaat-menambah pengetahuan (Mf)

Gambar 8 adalah hasil analisis frekuensi untuk butir pertanyaan nomor 17, yang terkait dengan indikator menambah pengetahuan. Hasil analisis frekuensi yang ditunjukkan pada Gambar 8, diketahui bahwa indikator menambah pengetahuan (Mf) sebanyak 3 responden menjawab Tidak Setuju (TS) dengan persentase 4,5\%, selanjutnya 40 responden menjawab Setuju (S) dengan persentase 59,7\%, dan 24 responden menjawab Sangat Setuju (SS) dengan persentase $35,8 \%$. Sehingga indikator manfaat memiliki tingkat kesuksesan sangat baik.

\begin{tabular}{|c|c|c|c|c|c|}
\hline \multicolumn{6}{|c|}{ MF1 } \\
\hline & & Frequency & Percent & Valid Percent & $\begin{array}{c}\text { Cumulative } \\
\text { Percent }\end{array}$ \\
\hline \multirow[t]{4}{*}{ Valid } & 1 & 3 & 4,5 & 4,5 & 4,5 \\
\hline & 2 & 40 & 59,7 & 59,7 & 64,2 \\
\hline & 3 & 24 & 35,8 & 35,8 & 100,0 \\
\hline & Total & 67 & 100,0 & 100,0 & \\
\hline
\end{tabular}

Gambar 8. Analisis frekuensi manfaat pada PTS Jombang

7) Struktur Organisasi

Gambar 9 adalah hasil analisis frekuensi untuk butir pertanyaan nomor 18 sampai 21 yang terkait dengan variabel struktur organisasi.

Hasil analisis frekuensi yang ditunjukkan pada Gambar 9 diketahui bahwa :

a. Indikator peningkatan kinerja (So1), sebanyak 1 responden menjawab Setuju (S) dengan persentase 25\% dan 3 responden menjawab Sangat Setuju (SS) dengan persentase $75 \%$. Sehingga indikator peningkatan kinerja memiliki tingkat kesuksesan sangat baik.

b. Indikator pembaharuan perangkat (So2), sebanyak 2 responden menjawab Setuju (S) dengan persentase 50\%, dan 2 responden menjawab Sangat Setuju (SS) dengan persentase 50\%. Sehingga indikator pembaharuan perangkat memiliki tingkat kesuksesan sangat baik. 
A. H. Mujianto dkk./Register 3 (1) 24-33

c. Indikator dukungan (So3), sebanyak 2 responden menjawab Setuju (S) dengan persentase $50 \%$,
dan 2 responden menjawab Sangat Setuju (SS) dengan persentase $50 \%$. Sehingga indikator dukungan memiliki tingkat kesuksesan sangat baik.

d. Indikator fasilitas (So4), sebanyak 2 responden menjawab Setuju (S) dengan persentase 50\%, dan 2 responden menjawab Sangat Setuju (SS) dengan persentase 50\%. Sehingga indikator fasilitas memiliki tingkat kesuksesan sangat baik.

\begin{tabular}{|c|c|c|c|c|c|c|c|c|c|c|c|}
\hline \multicolumn{6}{|c|}{ So1 } & \multicolumn{6}{|c|}{ So3 } \\
\hline & & Frequency & Percent & Valid Percent & $\begin{array}{l}\text { Cumulative } \\
\text { Percent }\end{array}$ & & & Frequency & Percent & Valid Percent & $\begin{array}{l}\text { Cumulative } \\
\text { Percent }\end{array}$ \\
\hline \multirow[t]{3}{*}{ Valid } & 2 & 1 & 25,0 & 25,0 & 25,0 & Valid & 2 & 2 & 50,0 & 50,0 & 50,0 \\
\hline & 3 & 3 & 75,0 & 75,0 & 100,0 & & 3 & 2 & 50,0 & 50,0 & 100,0 \\
\hline & Total & 4 & 100,0 & 100,0 & & & Total & 4 & 100,0 & 100,0 & \\
\hline \multicolumn{6}{|c|}{ So2 } & \multicolumn{6}{|c|}{ So4 } \\
\hline & & Frequency & Percent & Valid Percent & $\begin{array}{c}\text { Cumulative } \\
\text { Percent }\end{array}$ & & & Frequency & Percent & Valid Percent & $\begin{array}{c}\text { Cumulative } \\
\text { Percent }\end{array}$ \\
\hline \multirow[t]{3}{*}{ Valid } & 2 & 2 & 50,0 & 50,0 & 50,0 & \multirow[t]{3}{*}{ Valid } & 2 & 2 & 50,0 & 50,0 & 50,0 \\
\hline & 3 & 2 & 50,0 & 50,0 & 100,0 & & 3 & 2 & 50,0 & 50,0 & \multirow[t]{2}{*}{100,0} \\
\hline & Total & 4 & 100,0 & 100,0 & & & Total & 4 & 100,0 & 100,0 & \\
\hline
\end{tabular}

Gambar 9. Analisis Frekuensi Struktur Organisasi PTS di Jombang

Tabel 3. Penilaian Sistem

\begin{tabular}{cll}
\hline Skor & \multicolumn{1}{c}{ Kualifikasi } & Hasil \\
\hline $85-100 \%$ & Sangat Baik & Berhasil \\
$65-84 \%$ & Baik & Berhasil \\
$55-64 \%$ & Cukup & Tidak Berhasil \\
$0-54 \%$ & Kurang & Tidak Berhasil \\
\hline
\end{tabular}

Berdasarkan hasil analisis didapatkan 3 indikator dengan nilai kepuasan di bawah 85\%, yaitu kecepatan waktu respon (KS2) dengan nilai 76,1\%; fasilitas petunjuk penggunaan (bantuan) (KS3) dengan nilai 71,6\%; dan kepuasan tampilan (KP3) dengan nilai 64,2\%; sehingga perlu ditingkatkan agar sistem dapat dikatakan sangat baik, hal ini mengacu pada penilaian sistem menurut (Arikunto, 2010) yang dijelaskan pada Tabel 3.

Berikut ini penyajian rekapitulasi penilaian berdasarkan 7 variabel model kesuksesan HOT Fit yang ditunjukkan Tabel 4.

Tabel 4. Rekapitulasi Penilaian PMB PTS di Jombang Berdasarkan 7 Variabel HOT Fit (diadaptasi dari Nugroho, Utami, dan Taufiq (2013))

\begin{tabular}{|c|c|c|c|c|c|c|c|c|c|c|}
\hline \multirow{2}{*}{$\begin{array}{c}\text { Rekapitulasi Jawaban } \\
\text { Responden }\end{array}$} & \multicolumn{2}{|c|}{0 (STS) } & \multicolumn{2}{|c|}{1 (TS) } & \multicolumn{2}{|c|}{$2(S)$} & \multicolumn{2}{|c|}{3} & \multicolumn{2}{|c|}{ Jumlah } \\
\hline & $\mathbf{F}$ & $\%$ & $\mathbf{F}$ & $\%$ & $\mathbf{F}$ & $\%$ & $\mathbf{F}$ & $\%$ & $\mathbf{F}$ & $\%$ \\
\hline Kualitas Sistem & 1 & 0,37 & 40 & 14,93 & 145 & 54,10 & 82 & 30,60 & 268 & 100,00 \\
\hline Kualitas Informasi & 0 & 0,00 & 21 & 5,22 & 248 & 61,69 & 133 & 33,08 & 402 & 100,00 \\
\hline Kualitas Layanan & 0 & 0,00 & 8 & 6,06 & 78 & 59,09 & 46 & 34,85 & 132 & 100,00 \\
\hline Pengguna Sistem & 1 & 1,49 & 8 & 11,94 & 36 & 53,73 & 22 & 32,84 & 67 & 100,00 \\
\hline Kepuasan Pengguna & 0 & 0,00 & 29 & 14,80 & 124 & 63,27 & 43 & 21,94 & 196 & 100,00 \\
\hline Manfaat & 0 & 0,00 & 3 & 4,48 & 40 & 59,70 & 24 & 35,82 & 67 & 100,00 \\
\hline Struktur Organisasi & 0 & 0,00 & 0 & 0,00 & 7 & 43,75 & 9 & 56,25 & 16 & 100,00 \\
\hline Total & \multicolumn{2}{|r|}{2} & \multicolumn{2}{|c|}{110} & \multicolumn{2}{|c|}{677} & \multicolumn{2}{|c|}{359} & \multicolumn{2}{|c|}{1148} \\
\hline Rata-rata (\%) & \multicolumn{2}{|c|}{0,17} & \multicolumn{2}{|c|}{9,58} & \multicolumn{2}{|c|}{58,97} & \multicolumn{2}{|c|}{31,27} & \multicolumn{2}{|c|}{100,00} \\
\hline
\end{tabular}

Berdasarkan data pada Tabel 4, diketahui bahwa secara keseluruhan website PMB online PTS di Jombang sudah baik, hal ini ditunjukkan dengan 58,97\% responden menjawab Setuju (S) dan 31,27\% responden menjawab Sangat Setuju (SS).

\section{Kesimpulan}

Berdasarkan hasil pembahasan sebelumnya dapat disimpulkan beberapa hal diantaranya sebagai berikut : 
a. Tingkat kesukesan penerapan website PMB online PTS di Jombang adalah sebesar 90,24\% (penjumlahan jawaban responden setuju dengan jawaban sangat setuju). Detail tingkat kesuksesan pada tiap variabel adalah kualitas sistem sebesar $84,7 \%$, kualitas informasi sebesar $94,77 \%$, kualitas layanan sebesar $93,94 \%$, pengguna sistem sebesar $86,57 \%$, kepuasan pengguna sebesar $85,21 \%$, manfaat sebesar $95,52 \%$, dan struktur organisasi sebesar $100 \%$. Sehingga tingkat kesuksesan penerapan website PMB online PTS di Jombang dapat dikatakan sangat baik.

b. Meskipun keseluruhan penilaian website PMB online PTS di Jombang dinyatakan sangat baik, tetapi terdapat terdapat 3 indikator yang masih perlu ditingkatkan karena memiliki nilai keberhasilan di bawah 85\%, yaitu kecepatan waktu respon (KS2) dengan nilai keberhasilan $76,1 \%$, fasilitas petunjuk penggunaan (bantuan) (KS3) dengan nilai keberhasilan 71,6\%, dan kepuasan tampilan (KP3) dengan nilai keberhasilan 64,2\%.

c. Aspek-aspek yang perlu ditingkatkan pada website PMB online PTS di Jombang adalah, (1) untuk meningkatkan kecepatan loading website dapat dengan mengoptimalkan (memperkecil) ukuran gambar atau animasi yang terdapat pada website; (2) untuk membantu calon mahasiswa dalam pencarian informasi dapat dilakukan dengan penambahan video tutorial atau animasi; dan (3) untuk meningkatkan kepuasan tampilan halaman utama website PMB online PTS di Jombang dapat ditambahkan informasi kontak PMB dan media sosial dari kantor PMB.

\section{Referensi}

Arikunto, S. (2010). Prosedur Penelitian: Suatu Pendekatan Praktik. Jakarta: Rineka Cipta.

Fatmawati, F. (2016). Perancangan sistem informasi pemesanan katering berbasis web pada rumah makan Tosuka Tangerang. Jurnal Teknik Komputer AMIK BSI, 2(2), 33-41.

Gunawan, M. A. (2015). Statistik Penelitian Bidang Pendidikan, Psikologi \& Sosial. Yogyakarta: Parama Publishing.

Krisbiantoro, D., Suyanto, M., \& Luthfi, E. T. (2015). Evaluasi keberhasilan implementasi sistem informasi dengan pendekatan HOT Fit model (Studi kasus: Perpustakaan STMIK AMIKOM Purwokerto). Konferensi Nasional Sistem \& Informatika. Denpasar: STMIK STIKOM Bali.

Nugroho, N., Utami, E., \& Taufiq, E. (2013). Analisis perbandingan kualitas pelayanan Penerimaan Mahasiswa Baru (PMB) online menggunakan model kesuksesan sistem informasi DeLone dan McLean (D\&M) (Studi kasus : PMB UKDW dan PMB STMIK AMIKOM Yogyakarta). RESPATI: Jurnal Ilmiah Teknologi Informasi, 8(24).

Pant, A. (2015). Usability evaluation of an academic library website Experience with the Central Science Library, University of Delhi. The Electronic Library, 33(5), 896-915.

Sugiyono, S. (2010). Statistik Untuk Penelitian. Bandung: Alfabeta.

Utomo, A. P. (2014). Pemodelan arsitektur enterprise sistem informasi akademik pada perguruan tinggi menggunakan Enterprise Architecture Planning. Jurnal SIMETRIS, 5(1), 33-40.

Wei, Q., Chang, Z., \& Cheng, Q. (2015). Usability study of the mobile library App: an example from Chongqing University. Library Hi Tech, 33(3), 340-355.

Yusof, M. M., Paul, R. J., \& Stergioulas, L. K. (2006). Towards a framework for health information systems evaluation. HICSS'06. Proceedings of the 39th Hawaii International Conference on System Sciences. Kauia: IEEE. 